\title{
Young male with left adrenal mass
}

\author{
Abdul-Wahed Nasir Meshikhes, ${ }^{1}$ Wael M Abdel Gawad, ${ }^{2}$ Jamal Youssef Al-Saeed ${ }^{3}$
}

${ }^{1}$ Department of Surgery, King Fahad Specialist Hospital, Dammam, Saudi Arabia ${ }^{2}$ Department of Surgical Oncology, National Cancer Institute, Cairo, Egypt ${ }^{3}$ Department of Endocrinology, King Fahad Specialist Hospital, Dammam, Saudi Arabia

\section{Correspondence to} Dr Abdul-Wahed Nasir Meshikhes,

meshikhes@gmail.com

Accepted 3 July 2016
CrossMark

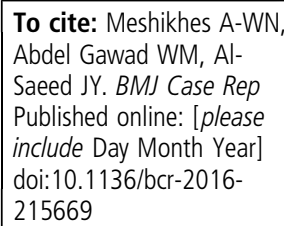

\section{DESCRIPTION}

A 20-year-old male patient presented with a 5 -month history of left hypochondriac pain and mass. He denied any associated constitutional symptoms. Clinically, he was overweight with no cushingoid or virilising features. Abdominal examination revealed a huge non-tender mass arising from the left hypochondrium. There was no hepatomegaly and the testicles were normal.

Routine blood investigations including tumour markers and plasma and urine hormonal assays were normal. CT scan (figure 1A) and MRI (figure 1B) revealed a large left retroperitoneal mass $(15 \times 12 \mathrm{~cm})$ with small bilateral lung deposits. After excluding phaeochromocytoma, US-guided

A
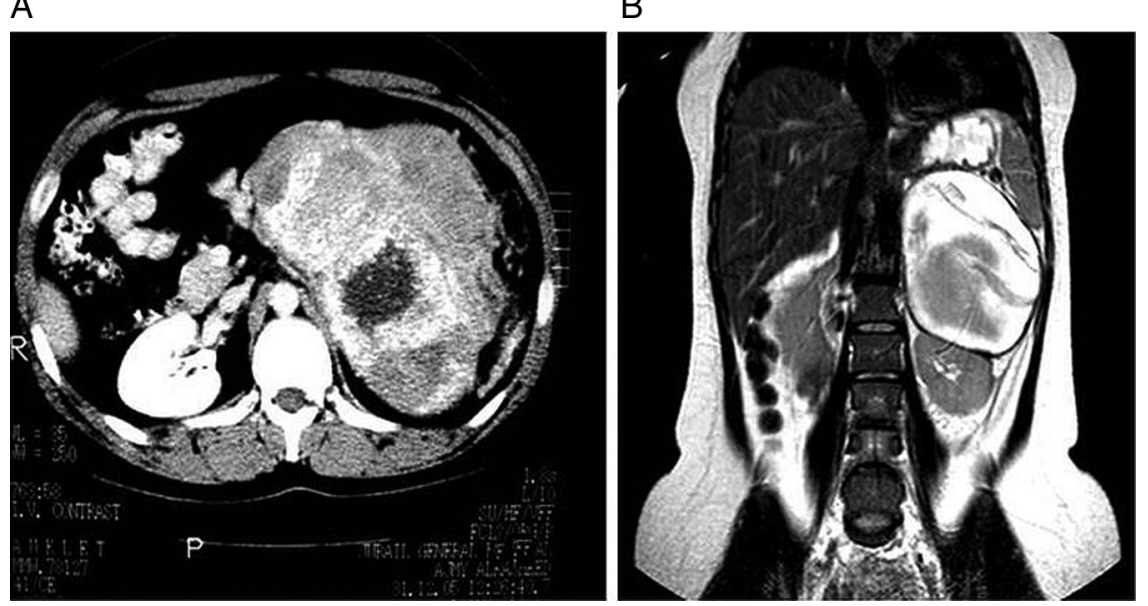

Figure 1 CT scan (panel 1A) and MRI (panel 1B) of the left adrenal mass showing the inhomogeneous appearance of the lesion with necrosis in both imaging modalities. Differential diagnoses include benign solid tumours (eg, oncocytoma of the kidney or adrenocortical adenoma) and malignant lesions (eg, hypernephroma or adrenocortical tumour). The low fat content differentiates this lesion from benign adrenocortical adenoma.

A

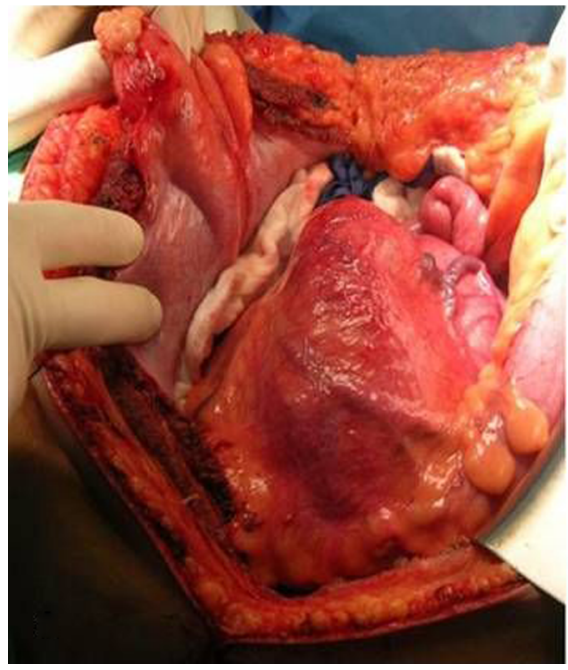

B

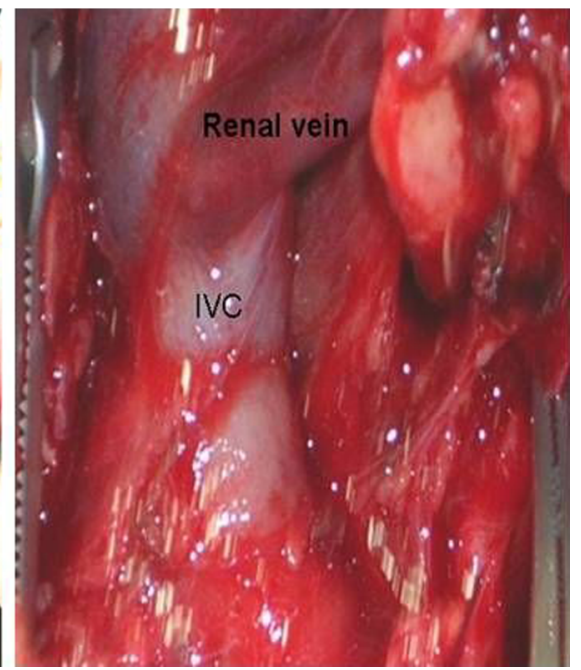

Figure 2 Photograph of the adrenal mass at laparotomy before surgical resection (panel A). Panel B showing the operative site after the resection of the mass with the preserved left renal vein and inferior vena cava.

transcutaneous biopsy raised the possibility of nonfunctioning adrenocortical carcinoma (ACC). revealed locally advanced adrenal hepatic deposits. Hence, a palliative resection was carried out (figures 2B) and the histopathology ACC (weight: $2.11 \mathrm{~kg}$; size: $24 \times 10 \times 9 \mathrm{~cm}$ ) with negative lymph nodes (figure 3 ) vimentin, inhibin and cytokeratin. He was later lost to follow-up and therefore presumed dead after 3 months.

ACC is a rare tumour which has poor prognosis and the 5 -year survival rate is barely $20 \% .{ }^{1}$ Distant metastases at presentation occur in $50 \%$ of cases. ${ }^{1}$

B 
Figure 3 Low-power magnification microphotograph of the tumour (panel A) featuring sheets and nests of malignant epithelial cell with eosinophilic cytoplasm and pleomorphic nuclei. Areas of tumour necrosis are also seen $(H \& E \times 40)$. Panel $B$ is featuring sheets of tumour cells with prominent nuclear pleomorphism and several mitoses are present $(H \& E \times 400)$.
A

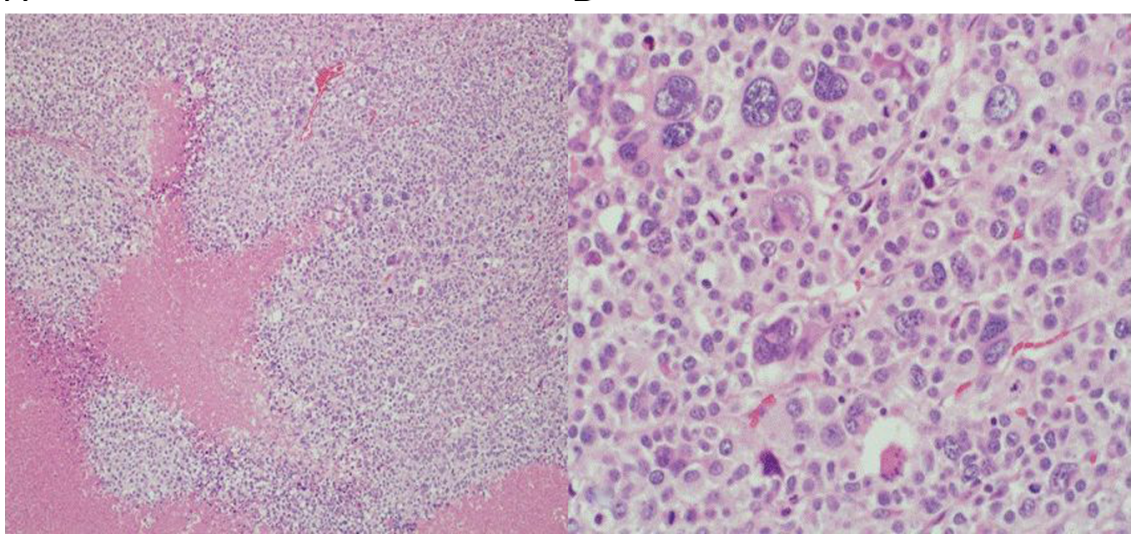

Preoperative transcutaneous biopsy-though performed in this case-may not be necessary and has a complication rate of $11 \%$, but $70 \%$ diagnostic sensitivity. ${ }^{2}$ Although the resectability rate is $50 \%,{ }^{3}$ treatment is by aggressive surgical resection with or without lymph node dissection even in presence of metastases. ${ }^{13}$

ACC exhibits poor response to chemotherapy, but mitotane remains the only drug that produces tumour and metastatic regression in incompletely-resected or non-resectable carcinomas.

\section{Learning points}

- Adrenocortical carcinoma is a rare tumour which is often large in size, locally advanced and metastatic at presentation.

- It is associated with poor prognosis; the 5-year survival rate barely exceeds $20 \%$.

- Although the resectability rate is $<50 \%$, treatment is aggressive surgical resection with or without lymph node dissection even in presence of metastases.
Twitter Follow Abdul-Wahed Meshikhes at @meshikhes

Acknowledgements The authors would like to acknowledge Dr Samir Amr, chairman of the pathology department, King Fahad Specialist Hospital, Dammam and Dr Fouad Al-Dayel, Consultant pathologist, King Faisal Specialist Hospital and Research Centre, Riyadh, Saudi Arabia for providing the pathology microphotographs with the legends.

Contributors A-WNM was the primary physician who managed the case. He wrote the final draft. WMAG participated in the management of the case, searched the literature and wrote the initial draft. JYAI-S shared the medical treatment of the case and helped in the initial draft.

Competing interests None declared.

Patient consent Obtained.

Provenance and peer review Not commissioned; externally peer reviewed.

\section{REFERENCES}

1 Kerkhofs TM, Verhoeven RH, Van der Zwan JM, et al. Adrenocortical carcinoma: a population-based study on incidence and survival in the Netherlands since 1993. Eur J Cancer 2013;49:2579-86.

2 Williams AR, Hammer GD, Else T. Transcutaneous biopsy of adrenocortical carcinoma is rarely helpful in diagnosis, potentially harmful, but does not affect patient outcome. Eur J Endocrinol 2014;170:829-35.

3 Miller BS, Doherty GM. Surgical management of adrenocortical tumours. Nat Rev Endocrinol 2014;10:282-92.

Copyright 2016 BMJ Publishing Group. All rights reserved. For permission to reuse any of this content visit http://group.bmj.com/group/rights-licensing/permissions.

BMJ Case Report Fellows may re-use this article for personal use and teaching without any further permission.

Become a Fellow of BMJ Case Reports today and you can:

- Submit as many cases as you like

- Enjoy fast sympathetic peer review and rapid publication of accepted articles

- Access all the published articles

- Re-use any of the published material for personal use and teaching without further permission

For information on Institutional Fellowships contact consortiasales@bmjgroup.com

Visit casereports.bmj.com for more articles like this and to become a Fellow 